\title{
海水成分を用いて生成する アルミニウムの化学皮膜に関する研究
}

\author{
内山 利光*, 長谷川 実*, 松本 裕志*
}

\author{
A Study on Chemical Conversion Coatings \\ Formed on Aluminum in Boiling Sea Water
}

Toshiteru UCHIYAMA*, Minoru HASEGAWA* and Hiroshi MATSUMOTO*

\begin{abstract}
During corrosion tests on aluminum specimens in natural or synthetic sea-water, pitting corrosion of the surfaces occurs. Except for the local sites of pitting, however, the formation of a milk white film is generally observed. In regions covered with this film, pitting corrosion hardly occurs even if the corrosion test is continued for a prolonged period. Based on this observation, it was attempted to obtain corrosion-resistant conversion coatings by utilizing sea-water or solutions containing selected compounds of sea-water.

The following results were obtaind.

(1) When aluminum specimens were dipped in boiling ASTM sea-water, a uniform conversion coating was formed on their surfaces. The coating was found to consist of two distinct layers : an outer layer containing magnesium and aluminum, and an inner dense layer containing only aluminum.

(2) Magnesium chloride, sodium hydrogen carbonate and sodium sulfate were found to be essential in obtaining uniform, corrosion resistant conversion coatings.

(3) The corrosion resistance of the conversion coatings formed in ASTM synthetic sea-water was found to be better than that of boehmite films commonly used for the corrosion-protection in aluminum heat exchangers.
\end{abstract}

\section{1. 緒}

天然海水あるいは人工海水中で無処理アルミニウム材 料の浸せき腐食試験を行うと, しばしば孔食発生部以外 の表面に乳白色皮膜の生成する現象が認められる1)。著 者らの経験ではその後の長期間にわたる浸せき試験にお。 いてもいったん皮膜が生成したアルミニウム表面には, あらたに孔食の発生をみることは少なく，生成皮膜それ 自身が海水に対し良好な耐食性を有しているものと考え られる。同様の現象は海洋温度差発電用熱交換器にアル ミニウムを用いた研究においても報告されている2。

著者らは，上述のような現象をもとに高温海水中でア ルミニウムの浸せき処理を行らことにより化学皮膜生成 の可能性を検討し，その結果無公害かつ安価で防食性に すぐれた化学皮膜を生成させらることを見い出した。本 報では高温海水中で生成する皮膜の組成，構造ならびに 耐食性について検討するととるに皮膜生成に関与する海 水成分を抽出して処理夜系を単純化することを試み，各 成分の濃度, $\mathrm{pH}$, 処理温度等の皮膜生成に及ぼす影響に

* 昭和アルミニウム限（市590 大阪府堺市海山町6-224） Showa Aluminum Corporation (6-224, kaisancho, Sakai -shi, Osaka 590)
ついても検討を加えたので報告する。

\section{2. 実 験 方 法}

\section{2-1 試料}

試料は厚さ $1 \mathrm{~mm}$, 純度 $99.0 \%$ 以上の純アルミニウム （A1100-H24）を用いた。前処理として30\%硝酸にて 脱脂後水洗を行い, その後 $5 \%$ 水酸化ナトリウム溶液中 で $45^{\circ} \mathrm{C} ， 5$ 分間エッチングを行い水洗ののち $30 \%$ 硝酸に てデスマット，水洗，乾燥を行い化成処理に供した。

\section{2-2 化成処理および皮膜生成量の測定}

処理液として天然海水 (大阪湾上り採取), ASTM 人 工海水 ${ }^{3)}$ (以下人工海水と略称) を用いた。さらに, 皮 膜生成に及ぼす海水含有成分の影響を検討するため塩化 マグネシウム, 塩化カルシウム, 硫酸ナトリウム, 重炭 酸ナトリウム, 塩化ナトリウムの混合溶液を用い比液量 $1 \mathrm{~L} / \mathrm{dm}^{2}$ にて化成処理を行った。試薬はいずれも特級を 用いた。

皮膜生成量の測定は後述するように生成皮膜が硝酸に 易溶な上層之難溶な下層から成るため 1 規定硝酸を用い て上層を除き，その後りン酸一クロム酸皮膜はく離液中 で沸騰温度にて30分間浸せき処理することにより下層を 除去し，それぞれの脱膜前後の重量測定により両層の生 
成量を求めた。

\section{2-3 皮膜の船析}

天然海水，人工海水および皮膜生成に影響を与える海 水成分の混合浴中で生成させた皮膜表面执よび断面の観 察は，日本電子製 JXA-50 A 走查型電子顕微鏡を用 い加速電压 $15 \mathrm{kV}$ にて行った。さらに生成皮膜の構成 成分を分析するため皮膜表面および皮膜上層を 1 規定硝 酸で除去した下層皮膜表面についてイオンマイクロアナ ライザー（拉製 IMA-S) 1 次イオン $\mathrm{Ar}^{+}$, 加速電 王 $10 \mathrm{keV}$, ビーム径 $500 \mu \mathrm{m} \phi$ の条件で定性分析を行 とともに，上層皮膜を 1 規定硝酸で溶解させた溶液を原 子吸光分析法，吸光光度法により，定量分析を行った。 また下層皮膜については硝酸により上層皮膜を除去した 表面を赤外分光光度計（日本分光制DS-403G）に上り 反射法で入射角 $65^{\circ}$ 偏光 $+45^{\circ}$ の条件でスペクトルを測 定した。

\section{2-4 耐食性試娩}

耐食性試㪘として人工海水，上水道水（堺市上水道 水）中で，また促進耐食性試験としてはアルミニウムの 孔食を促進させる食塩-硫酸銅水溶液 ${ }^{4)}(\mathrm{NaCl} 0.05 \%+$ $\left.\mathrm{CuSO}_{4} \cdot 5 \mathrm{H}_{2} \mathrm{O} 0.05 \%\right)$ 中で浸せき試験を行った。

試験温度は上水道水浸せき試験を除さいずれす室温で 行い,上水道水浸せき試験の場合， $85^{\circ} \mathrm{C} に て 8$ 時間保持 後16時間放冷を 1 サイクルとして䒜温, 冷却を繰り返し た。

なお，腐食試験に用いたフルミニウム試料は儀性陽極 材との合わせ板であるアルクラッド材（A7072-1100両 面クラッド材）である。

\section{3. 実験結果および考察}

\section{3-1 皮膜生成および皮膜の生成に関与する成分の椮} 討

人工海水，または天然海水を弱アルカリ性に調整した

Table 1 Probability of film formation in various solutions

\begin{tabular}{|c|c|}
\hline Treatment solution & $\begin{array}{l}\text { Probability of } \\
\text { film formation }\end{array}$ \\
\hline 1) natural sea water (in osaka bay) & formed \\
\hline 2) ASTM synthetic sea water*1, & $n$ \\
\hline 3) $\mathrm{NaCl}+\mathrm{Na}_{2} \mathrm{SO}_{4}+$ stock soln. $1^{* 2}+$ stock soln. $2^{* 2}$, & "r \\
\hline 4) $\mathrm{NaCl}+\mathrm{Na}_{2} \mathrm{SO}_{4}+$ stock soln. $1 * 2$ ) & not formed \\
\hline 5) $\mathrm{NaCl}+\mathrm{Na}_{2} \mathrm{SO}_{4}+\mathrm{MgCl}_{2}$ & $" \prime$ \\
\hline 6) $\mathrm{NaCl}+\mathrm{Na}_{2} \mathrm{SO}_{4}+\mathrm{CaCl}_{2}$ & " \\
\hline 7) $\mathrm{NaCl}+\mathrm{Na}_{2} \mathrm{SO}_{4}+\mathrm{MgCl}_{2}+\mathrm{NaHCO}_{3}$ & formed \\
\hline $\mathrm{MgCl}_{2}+\mathrm{NaHCO}_{3}$ & $" t$ \\
\hline $\mathrm{CaCl}_{2}+\mathrm{NaHCO}_{3}$ & not formed \\
\hline $\mathrm{MkCl}_{2}+\mathrm{CaCl}_{2}+\mathrm{NaHCO}_{3}$ & formed \\
\hline$+\mathrm{MgCl}_{2}+\mathrm{NaHCO}_{3}$ & $n$ \\
\hline $\mathrm{Na}_{2} \mathrm{SO}_{4}+\mathrm{MgCl}_{2}+\mathrm{NallCO}_{3}$ & $"$ \\
\hline
\end{tabular}

[Treatment conditions] concentration of salts : same with ASTM synthetic sea water (ASTM D 1141-52) PH : 8.2 lemperature: $95 \mathrm{C}$ up iime : $30 \mathrm{~min}$

*1 1 ASTM synthetic sea water : prepared based on ASTM D 11415 *2' stock solution I, stock solution 2 : prepared based on ASTM D 114152
のち沸騰温度でアルミニウムの化成処理を行らと，その 表面には均一な乳白色の皮膜が生成する。表 1 亿天然海 水, 人工海水扣よび人工海水組成を順次単純化し, 処理 液の成分を絞り込んで調整した溶液中で化成処理を行い 皮膜生成の有無を評価した試験結果を示す。人工海水は 16種類の無機塩より構成されているが，海水中の成分全 てが皮膜生成に関与するのではなく，人下海水成分の中 では塩化マグネシウム括よび重炭酸ナトリウムが皮膜生 成に必要不可欠な成分であることがわかる。

图 1 に処理液 1 (天然海水), 処理液 2 (人工海水), 処理液 $8\left(\mathrm{MgCl}_{2}+\mathrm{NaHCO}_{3}\right)$, および処理液 $12\left(\mathrm{MgCl}_{2}\right.$ $\left.+\mathrm{NaHCO}_{3}+\mathrm{Na}_{2} \mathrm{SO}_{4}\right)$ により得られた皮膜の走榃型電 子顕砤鏡による表面形態の観察結果を示した。皮膜形態 は天然海水，人工海水による皮膜いずれる海綿状のポー ラスな形態を示すが，液系が最も単純化した処理液 8 で は針状形態を示し天然海水, 人工海水の場合と異なって いる。しかし, 処理液 8 にさらに硫酸ナトリウムを添加 した処理夜12の場合，皮膜形態は針状から海綿状の形態 になり天然海水，人工海水による皮膜と同様の形態を示 すことから，生成される皮膜形態に硫酸イオンが大きく 影響を与えているものと考えられる。

海水成分溶液中での皮膜生成可能性の検討，拉よび皮 膜形態がらの検討により天然海水，人工海水に上る皮膜 と同形態の皮膜を形成させるには塩化マグネシウム，重 炭酸ナトリウム, 硫酸ナトリウムの必要なことがわかっ た。
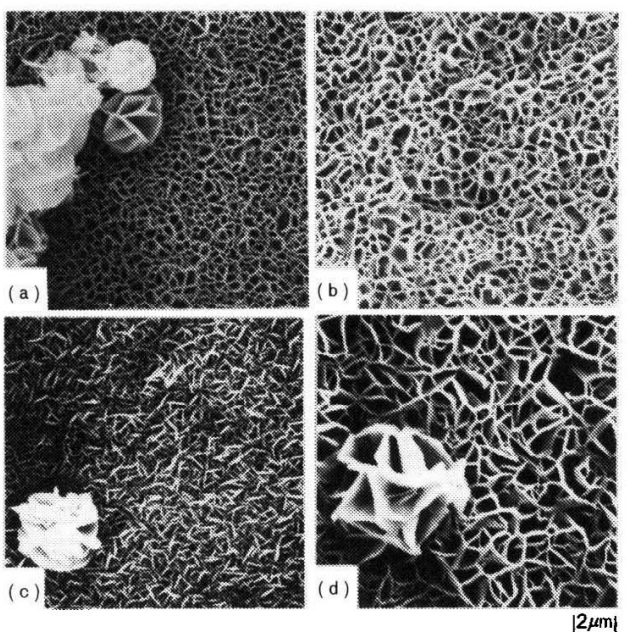

$2 \mu \mathrm{m}$

Fig. 1 SEM micrographs of film formed in Various treatment solutions 1), 2), 8), 12)

(a) natural seawater

(b) ASTM synthetic seawater

(c) $\mathrm{MgCl}_{2} \cdot 6 \mathrm{H}_{2} \mathrm{O} ; 11.1 \mathrm{~g} / \mathrm{L}+\mathrm{NaHCO}_{8} ; 0.2 \mathrm{~g} / \mathrm{L}$

(d) $\mathrm{MgCl}_{2} \cdot 6 \mathrm{H}_{2} \mathrm{O} ; 11.1 \mathrm{~g} / \mathrm{L}+\mathrm{NaHCO}_{3} ; 0.2 \mathrm{~g} / \mathrm{L}$ $+\mathrm{Na}_{2} \mathrm{SO}_{4} ; 4.1 \mathrm{~g} / \mathrm{L}$

[Treatment conditions] PH: 8.2

temperature $: 95^{\circ} \mathrm{C}$ up time : $30 \mathrm{~min}$ 


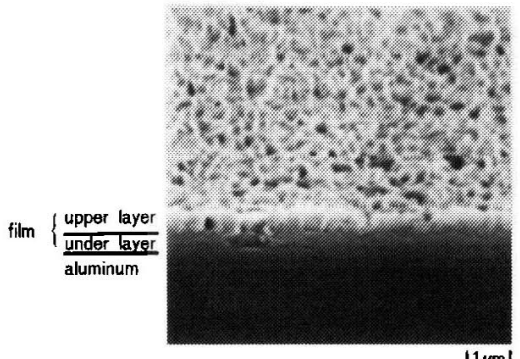

$11 \mu \mathrm{m}$

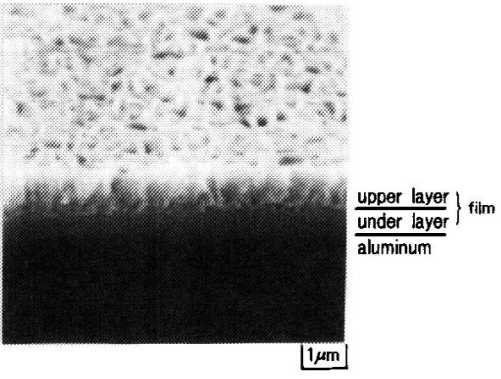

(b) Cross section of film formed in

$\mathrm{MgCl}_{2} \cdot 6 \mathrm{H}_{2} \mathrm{O} 11.1 \mathrm{~g} / \mathrm{L}+\mathrm{NaHCO}_{3} 0.2 \mathrm{~g} / \mathrm{L}+$ $\mathrm{Na}_{2} \mathrm{SO}_{4} 4.1 \mathrm{~g} / \mathrm{L}$ solution.

Fig. 2 Cross section micrographs of film formed in treatment solution 2) and 12)

[treatment conditons] PH : 8.2

temperature $: 95^{\circ} \mathrm{C}$ up time : $30 \mathrm{~min}$

(a) Cross secttion of film formed in ASTM synthetic seawater

\section{3-2 生成皮膜の構造および皮膜成分の分析}

人工海水, $\mathrm{MgCl}_{2}+\mathrm{NaHCO}_{3}+\mathrm{Na}_{2} \mathrm{SO}_{4}$ 溶液, $\mathrm{MgCl}_{2}$ $+\mathrm{NaHCO}_{3}$ 溶液中で沸騰温度にて処理して生成した皮 膜の構造と構成成分を中心に検討した。

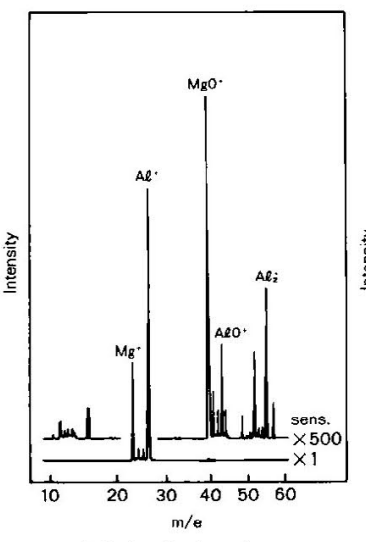

(a) after film formation

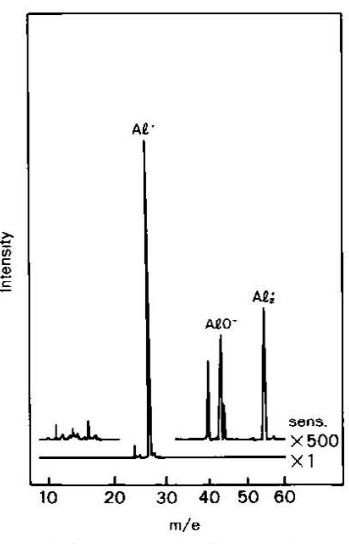

(b) after removing the upper layer
Fig. 3 Analysis of film formed in ASTM synthetic sea water by IMA

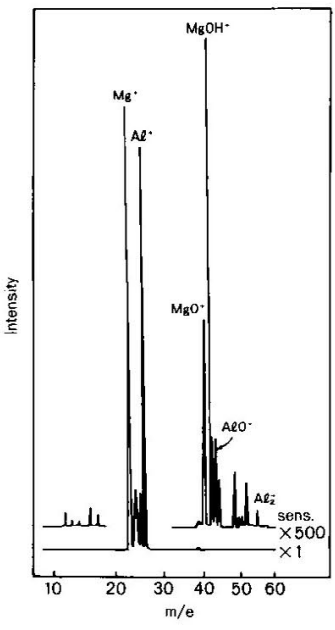

(a) after film formation

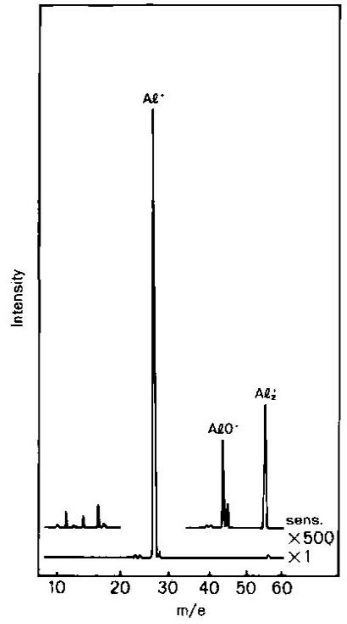

(b) after removing the upper layer
Fig. 4 Analysis of film formed in $\left(\mathrm{Na}_{2} \mathrm{SO}_{4}+\mathrm{MgCl}_{2}+\right.$ $\mathrm{NaHCO}_{8}$ ) solution by IMA
図 1（a）（b）（c）（d）にみられる皮膜はいずれる 1 規定硝酸に易溶な上層と難溶な下層の二層に分けるこ とができ，皮膜断面の観察を行ったところ図 2 に示した ように,ポーラスな上層と緻密な下層より成る二重構造 となっていることがわかった。

图 3，図4亿皮膜の上署部分招よび 1 規定硝酸にて上 層部分を溶解させた後の下層部表面のIMAによる成分 分析結果を示す。上層皮膜から検出された主な成分は $\mathrm{Al}^{+}$と $\mathrm{Mg}^{+}$であり，下層部分からは $\mathrm{Al}^{+}$が主に検出さ れた。従って上層部分はアルミニウムの水和物とマグネ シウムの水和物の複合化された皮膜，下層部分はアルミ 二ウムの水和物がほとんどの皮膜と推定される。なお， 人工海水による処理皮膜と $\mathrm{MgCl}_{2}+\mathrm{NaHCO}_{3}+\mathrm{Na}_{2} \mathrm{SO}_{4}$ 溶液による処理皮膜との間に大きな相違はみられなかっ た。

皮膜上層部分を 1 規定硝酸に溶解させ化学分析により 定量分析を行った結果を表 2 に示す。いずれの処理皮膜 とも上層部分にはナトリウム，カルンウム，硫酸イオン 程素イオンはほとんど含まれておらずマグネシウム， ア ルミニウムが主成分であった。 $\mathrm{Al} / \mathrm{Mg}$ の比を求めると 人工海水々 $\mathrm{MgCl}_{2}+\mathrm{NaHCO}_{3}+\mathrm{Na}_{2} \mathrm{SO}_{4}$ 溶液に上る処理 皮膜共，約 0.9 とい5值が得られ，一方 $\mathrm{MgCl}_{2}+$ $\mathrm{NaHCO}_{3}$ 溶液の場合には0.6の值であり，硫酸イオンの 存在した方がアルミニウムの量が多い。硫酸イオンは皮 膜構成成分にはなっていないが，上㬝部分のアルミニウ ム量增加に少なからず寄与し，組成的にも影響を与えて

\begin{tabular}{|c|c|c|c|c|c|c|}
\hline \multirow{2}{*}{ Treatment solution } & \multicolumn{6}{|c|}{ Chemical composition ( $w 1 \%)$} \\
\hline & $\mathrm{Mg}_{\mathrm{g}}$ & $\mathrm{Al}$ & $\mathrm{Na}$ & $\mathrm{Ca}$ & $\mathrm{Cl}$ & $\mathrm{SO}_{4}{ }^{2}$ \\
\hline natural seawater & 10.2 & 13.7 & - & - & - & - \\
\hline ASTM syuthetic seawater & 13.4 & 12.2 & - & .. & - & - \\
\hline $\mathrm{MgCl}_{2}+\mathrm{NaIICO}_{3}$ & 18.8 & 11.3 & - & - & & - \\
\hline $\mathrm{MgCl}_{2}+\mathrm{NaHCO}_{3}+\mathrm{Na}_{2} \mathrm{SO}_{4}$ & 15.3 & 14.2 & - & - & - & - \\
\hline $\begin{array}{l}\text { [Treatment conditions] } \\
\text { Composition : } \mathrm{MgCl}_{2} 6 \mathrm{H}_{2} \mathrm{O} \\
\mathrm{PH}: 8.2 \\
\text { temperature }: 95 \mathrm{C} \text { up } \\
\text { time : } 30 \mathrm{~min}\end{array}$ & $\lg / \mathrm{L}$. & $\mathrm{Na}_{2} \mathrm{SO}$ & 4. & & 10. de & cted \\
\hline
\end{tabular}




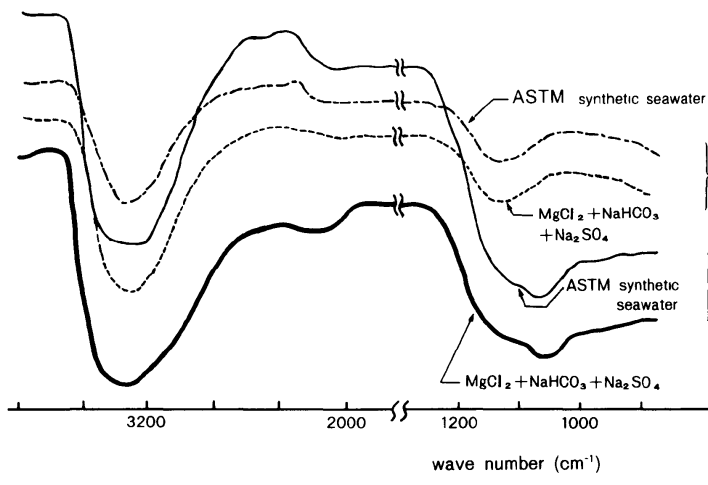

いるものと考えられる。

後述のように本処理皮膜は後処理として加圧水蒸気処 理を施すことにより皮膜生成量の増加等の特性向上がみ られ，殊に皮膜下層部分への影響が大きいため下層部分 について赤外吸収スペクトルを測定し図 5 に示す。人工 海水による皮膜, $\mathrm{MgCl}_{2}+\mathrm{NaHCO}_{3}+\mathrm{Na}_{2} \mathrm{SO}_{4}$ 溶液によ る皮膜のいずれも $3300 \sim 3100 \mathrm{~cm}^{-1}$ に $\mathrm{AlO}-\mathrm{H} \nu-\mathrm{OH}$ (伸 縮振動）による吸収就よび $1070 \sim 1050 \mathrm{~cm}^{-1}$ に Al-OH $\delta$ -OH (変角振動) による吸収がみられ擬ベーマイト化 ${ }^{5)}$ 〜)しているものと考えられる。

\section{3-3＼cjkstart皮膜生成量に及ぼす海水成分湿度の影䇺}

海水成分の中で皮膜生成に大きな影響を与えるのは硫 酸ナトリウム, 重炭酸ナトリウム, 塩化マグネシウムで あることがわかり，これらの濃度の皮膜生成量に及ぼす

影響を検討した。

硫酸ナトリウム添加量の影響を図 6 に示す。硫酸ナト リウム濃度が変化しても皮膜上層部分, 下層部分の生成 量にほとんど影響を与えず，生成量の観点からは無添加 の場合との違いはみられない。

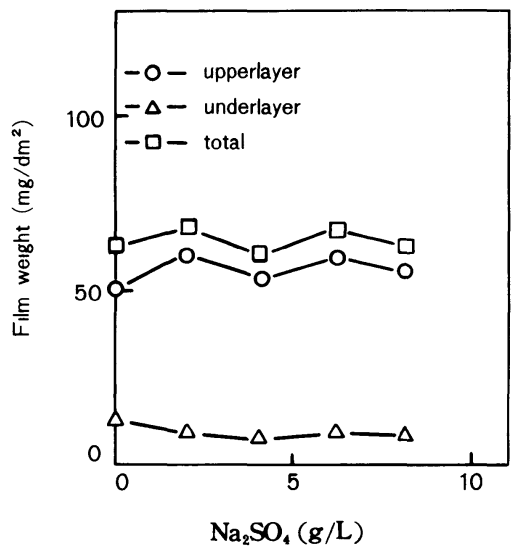

Fig. 6 Relationship between $\mathrm{Na}_{2} \mathrm{SO}_{4}$ concentration in treatment solution and film weight

[Treatment conditions]

composition: $\mathrm{MgCl}_{2} 6 \mathrm{H}_{2} \mathrm{O}: 11.1 \mathrm{~g} / \mathrm{L}+\mathrm{NaHCO}_{3}: 0.2 \mathrm{~g} / \mathrm{L}$ $\mathrm{PH}: 8.2$

temperature : $95^{\circ} \mathrm{C}$ up time : $30 \mathrm{~min}$ as film-formed

Fig. 5 IR spectra of under layer in film formed in ASTM synthetic sea water or $\mathrm{MgCl}_{2}+$ $\mathrm{NaHCO}_{3}+\mathrm{Na}_{2} \mathrm{SO}_{4}$ solution treatment with super-

heated water after film

formation
重炭酸ナトリウム添加量の影響を図 7 に示す。重炭酸 ナトリウム濃度については最適濃度か存在し, 約 $0.2 \mathrm{~g}$ $/ \mathrm{L} \sim 0.4 \mathrm{~g} / \mathrm{L}$ の間で上層皮膜の著しい生成かみられるが， 下層皮膜に対してはほとんど影響を与えていない。化成 処理時, 重炭酸ナトリウム添加量が少ない場合には試料 表面から微細なカス発生を伴って皮膜生成が認められて くるのに比べ, 添加量が過剰な場合には短時間で表面か らのガス発生が認められなくなった。これはアルミニウ ム表面が炭酸塩で被覆されたためアルミニウムの溶出が 抑制され，上層部分の生成量が小さくなったものと考え られる。

塩化マグネシウム濃度を変化させた場合の皮膜生成量 を図 8 に示す。塩化マグネシウム添加量の増加に伴い上 層部分の生成量の増加がみられるが，11 g/L 以上でほ ぼ飽和状態に到達する。このような状態に至っても処理 液の $\mathrm{pH}$ を上げることにより表面の反応を促進し，上層 部分の生成を増加させることができる。殊に塩化マグネ シウム濃度の低い場合 $(5 \mathrm{~g} / \mathrm{L})$ に皮膜生成効果が顕著 である。これは $\mathrm{pH}$ の上昇により皮膜中への $\mathrm{OH}^{-}$イ ンの拡散 ${ }^{8)}$ 量が增し, その結果アルミニウムの溶出が 多くなり皮膜生成の増加につながったものと考えられる。

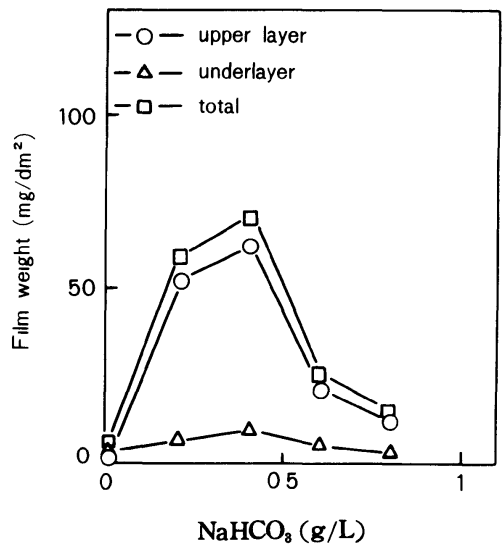

Fig. 7 Relationship between $\mathrm{NaHCO}_{3}$ concentration in treatment solution and film weight [Treatment conditions] composition : $\mathrm{MgCl}_{2} 6 \mathrm{H}_{2} \mathrm{O}: 11.1 \mathrm{~g} / \mathrm{L}+\mathrm{Na}_{2} \mathrm{SO}_{4}: 4.1 \mathrm{~g} / \mathrm{L}$ $\mathrm{PH}: 8.2$

temperature : $95 \mathrm{C}$ up time : $30 \mathrm{~min}$ 


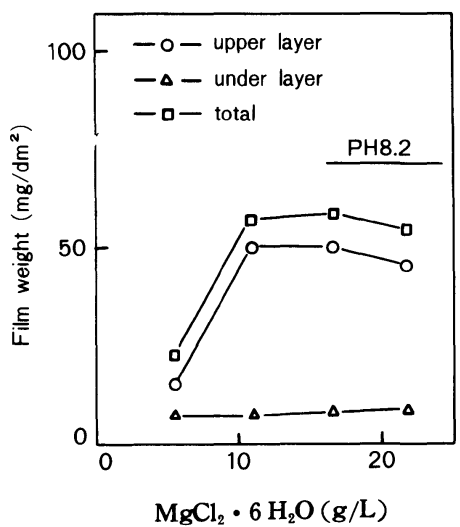

3-4 皮膜生成量に及ぼす処理温度, 処理時間, およ び皮膜生成処理後の加圧水蒸気処理の影響

処理温度を変化させた時の皮膜生成量を図 9 に示す。 処理温度 $90^{\circ} \mathrm{C}$ ま では上層皮膜，下層皮膜ともにゆるやか に成長するがその程度は小さい。 $100{ }^{\circ} \mathrm{C}$ に上層皮膜の 大きな生成量増加が認められ，アルミニウムイオンの急 激な溶出により下層皮膜の成長を伴いながら上層皮膜の 成長が大きく進んだものと考えられる。

一方処理時間の影響を図10に示す。下層皮膜はゆるや かな成長であるが上層皮膜は時間と共に成長が著しく， 放物線的な生成量の増加がみられる。

また皮膜生成処理後, 加圧水蒸気処理 $\left(4 \mathrm{~kg} / \mathrm{cm}^{2} 25\right.$ 分間）を行らと図9，図10に示したよらに皮膜重量の増 加が認められ, 殊に下層皮膜にその程度は著しく, 皮膜 生成処理温度, 処理時間に関係なくほぼ一定量の増加が みられる。下層皮膜はアルミニウム水和物がほとんどで

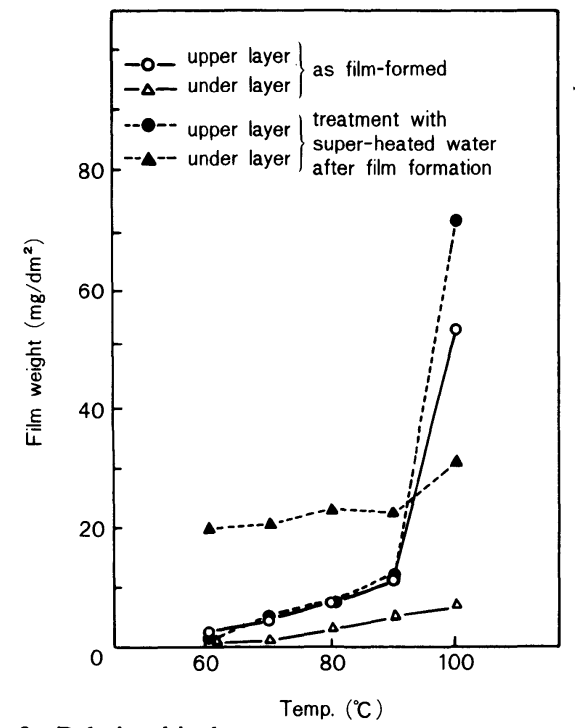

Fig. 9 Relationship between treatment temperature and film weight

[Treatment conditions]

composition : $\mathrm{MgCl}_{2} 6 \mathrm{H}_{2} \mathrm{O}: 11.1 \mathrm{~g} / \mathrm{L}+\mathrm{Na}_{2} \mathrm{SO}_{4}: 4.1 \mathrm{~g} / \mathrm{L}$ $+\mathrm{NaHCO}_{3}: 0.2 \mathrm{~g} / \mathrm{L}$

$\mathrm{PH}: 8.2$ time $: 30 \mathrm{~min}$
Fig. 8 Relationshipbetween $\mathrm{MgCl}_{2} \cdot 6 \mathrm{H}_{2} \mathrm{O}$ concentration in treatment solution and film weight

[Treatment conditions] composition : $\mathrm{Na}_{2} \mathrm{SO}_{4}$ :

$4.1 \mathrm{~g} / \mathrm{L}+\mathrm{NaHCO}_{8}: 0.2 \mathrm{~g} / \mathrm{L}$ temperature : $95^{\circ} \mathrm{C}$ up time : $30 \mathrm{~min}$

$\mathrm{MgCl}_{2} \cdot 6 \mathrm{H}_{2} \mathrm{O}(\mathrm{g} / \mathrm{L})$

あり，またアルミニウム水和皮膜（ベーマイト皮膜）は 加圧水蒸気処理により重量増加すること故,9) から本処理 の場合もベーマイト皮膜の場合と同様の効果が生じたも のと考えられる。

一方上層皮膜については，皮膜生成量の少ない領域の 皮膜を加圧水蒸気処理しても上層皮膜の増加はみられな いが，処理温度が高く処理時間の長い皮膜量の多い試料 を加圧水蒸気処理を行らと上層皮膜の皮膜重量も増加し， 上層皮膜の組成，構造などが影響していると考えられる が, 増加する機構については現在のところ, 明確になっ ていない。

\section{3-5 生成皮膜の耐食性試験}

このように海水成分を用いて生成した皮膜の耐食性に ついて，防食化学皮膜としてアルミニウム製熱交換器な ぞに実用されているべーマイト皮膜 ${ }^{10)}$ との比較につい て検討した。なお，耐食性試験に供した試料は各々の皮 膜を生成させた後，一層の耐食性向上を目的 ${ }^{9)}$ として 加圧水蒸気処理を行ったものである。

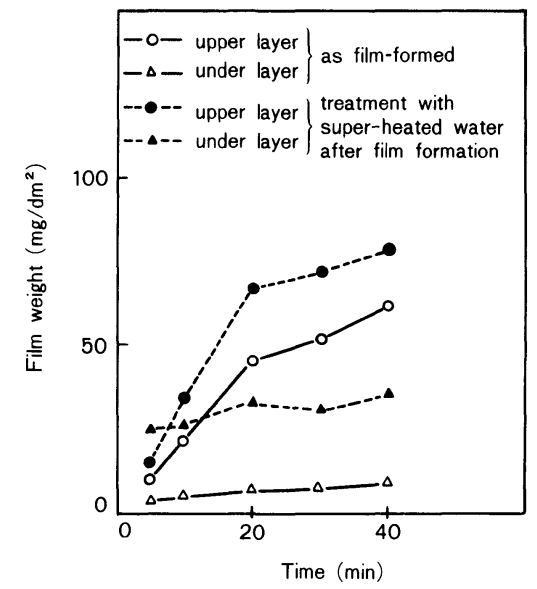

Fig.10 Relationship between treatment time and film weight

[Treatment conditions]

composition : $\mathrm{MgCl}_{2} \cdot 6 \mathrm{H}_{2} \mathrm{O}: 11.1 \mathrm{~g} / \mathrm{L}+\mathrm{NaSO}_{4}: 4.1 \mathrm{~g} / \mathrm{L}$ $+\mathrm{NaHCO}_{3}: 0.2 \mathrm{~g} / \mathrm{L}$

$$
\mathrm{PH}: 8.2
$$

temperature $: 95^{\circ} \mathrm{C}$ up 


\section{3-5-1 食塩-硫酸銅溶液浸せき促進腐食試験}

人工海水にて処理した試料, $\mathrm{MgCl}_{2}+\mathrm{NaHCO}_{3}+\mathrm{Na}_{2}$ $\mathrm{SO}_{4}$ 溶液による処理試料についてベーーイト処理試料と の比較で促進腐食試験を行った。な执，ベーマイト処理 は常法の通り0.3\%トリエタノールアミン溶液中 ${ }^{10)}$ で30 分間沸騰温度にて処理した。

図11(a)に試験後の腐食状況を示す。ペーマイト処理 試料には腐食液中の鈳イオンにより促進されたと思われ る孔食が多数発生し，同時に白色腐食生成物括上び金属 銅の析出がみられた。人工海水処理皮膜, $\mathrm{MgCl}_{2}+$ $\mathrm{NaHCO}_{3}+\mathrm{Na}_{2} \mathrm{SO}_{4}$ 溶液による処理皮膜に忙変色，腐食 の発生はなく，良好な耐食性（耐孔食性）を示した。

3-5-2 上水道水浸せき腐食試験および人工海水浸せ き腐食試験

食塩一硫酸銅溶液浸せき試験の場合同様，人工海水処 理試料, $\mathrm{MgCl}_{2}+\mathrm{NaHCO}_{3}+\mathrm{Na}_{2} \mathrm{SO}_{4}$ 溶液による処理試 料，べーマイト処理試料を腐食試験に供した。

高温での上水道水浸せき腐食試験結果を図11(b)に示 寸。ベーマイト処理試料には白色腐食生成物の付着と共 にアルクラッド材特有のへん平な孔食がみられたが，人 工海水処理試料, $\mathrm{MgCl}_{2}+\mathrm{NaHCO}_{3}+\mathrm{Na}_{2} \mathrm{SO}_{4}$ 溶液処理 試料には腐食の発生はみられず良好な耐食性を示した。

人工海水浸せき腐食試験においては，いずれの試料に む乳白色の微細粉末が付着し(ペーマイト処理試料の腐 食生成物か溶液側から付着したものと思われる)外観的 に灰色ムラ状に見齐るが容易に除去でき，この部分での 腐食の発生は認められなかった。ベーマイト処理試料に 岋白色腐食生成物を伴った孔食の発牛が認められたが人 工海水処理試料, $\mathrm{MgCl}_{2}+\mathrm{NaHCO}_{3}+\mathrm{Na}_{2} \mathrm{SO}_{4}$ 溶液処理 試料いずれにも腐食の発生は全く認められず良好な耐食 性を示した。

\section{4. 結}

海水中にてアルミニウムの腐食 試験を行らと孔食部以外の個所に 乳白色の皮膜生成が公られるが， 素地には腐食の発生が認められな いことを見い出したため，これら を手掛りに海水成分により耐食性 の良好な化成皮膜か人工的心得ら れないかどらかを検討し次の結論 友得た。

(1)天然海水またはASTM人工 海水中でフルミニウムを恶沸処理 することにより均一な皮膜を生成 させることができ，主としてマグ ネンウムとアルミニウムの水和物 から成る海綿状のポーラスな形態
を示す上層部分とアルミニウムの水和物がはとんどの緻 密な下層部分の二層から成る化成皮膜を゙得ることができ た。

（2）皮膜形成に必要な成分を検封したところ，皮膜形成 には睢化マグネシウム拈よび重炭酸ナトリウムの存在が 必要不可欠であり，また硫酸ナトりウムの添加は皮膜形 態に大きな影響を及ぼすことが判明しだ。

(3)生成した皮朕の耐食性はアルミニウムの防食化学攴 膜として実用されているべーマイト皮膜より甪孔食性に すぐれ，かつ高温の上水道水または人工海水に刘してあ 耐食性にすぐれた皮膜であることがわかった。

本処理方法は実用的な観点から二ニークな化学皮膜処 理と思われるが皮膜の生成反应，耐食性向上のメカ二ズ ムなどは今後の検討課題である。

(昭和151年 5 月，軽金属学会第50回大会にて一部発表)

(1985-9-2 受理)

\section{文献}

1）軽金属協会 海水淡水化委員会；軽金䖝，25，392（1975）

2) B. Little, J. Morse, et al ; Technical symposia of 1980 NACE, paper No. 43

3) ASTM D-1141-52

4）福島敏郎；金表誌，25，510（1974）

5) G.A. Dorsey Jr., ; J. Electrochem. Soc., 113, 169 (1966)

6）阿部 隆，津田俊二，富永哲生；金表誌，24，700（1973）

7) 阿部 隆, 相㳄浩二, 内山利光, 礒山水二；軽金瘏，24， 489 (1974)

8) J.W. Diggle and A.K. Vijk ; Oxides and Oxide Films, 4, 228, Marcel Dekker, New York (1976)

9）内山利光；軽金属学会第36回春期大会講演概要， p. 189 (1969)

10）浅野祐一郎，阿部 隆，内山利光，金井富挲；金表誌， 26 , 368 (1975) (a) $0.05 \% \mathrm{NaC} \ell+0.05 \% \mathrm{CuSO}_{4} \cdot 5 \mathrm{H}_{2} \mathrm{O}($ period : $100 \mathrm{~h})$

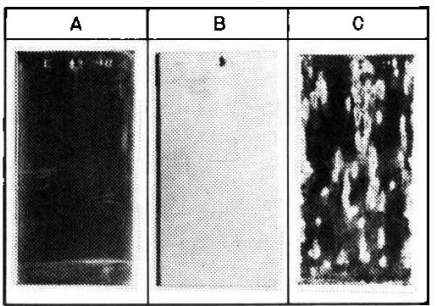

(o) ASTM synthetic seawater (period : 1year)

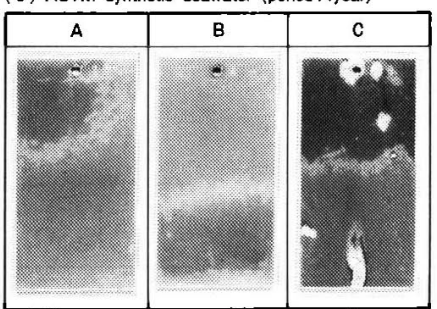

Fig.11 Surface corrosion behavior of film coated aluminum after immersing in various solutions (b) high temperature city water (period: 1year)

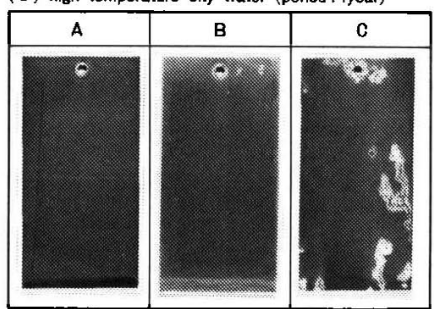

[Treatment conditions]

compositon A: ASTM synthetic seawater

B : $\mathrm{MgCl}_{2} \cdot 6 \mathrm{H}_{2} \mathrm{O} 11.1 \mathrm{~g} / \mathrm{L}$ $+\mathrm{NaHCO}_{3} 0.2 \mathrm{~g} / \mathrm{L}$ $+\mathrm{Na}_{2} \mathrm{SO}_{4} 4 . \mathrm{lg} / \mathrm{L}$

$\mathrm{C}: 0.3 \%$ Triethanolamine (boehmite process) temperature $: 95^{\circ} \mathrm{C}$ up time : $30 \mathrm{~min}$

treatment after

film formation : in super heated water $\left(4 \mathrm{~kg} / \mathrm{cm}^{2}, 25 \mathrm{~min}\right)$ 